\begin{tabular}{|c|c|c|c|c|c|c|}
\hline \multirow{4}{*}{ Impact Factor: } & ISRA (India) & $=3.117$ & SIS (USA) & $=0.912$ & ICV (Poland) & $=6.630$ \\
\hline & ISI (Dubai, UAE & $=0.829$ & РИНЦ (Russia) & $=0.156$ & PIF (India) & $=1.940$ \\
\hline & GIF (Australia) & $=0.564$ & ESJI (KZ) & $=8.716$ & IBI (India) & $=4.260$ \\
\hline & JIF & $=1.500$ & SJIF (Morocco) & $=5.667$ & OAJI (USA) & $=0.350$ \\
\hline
\end{tabular}

\section{SOI: $1.1 /$ TAS DOI: $10.15863 /$ TAS International Scientific Journal Theoretical \& Applied Science}

p-ISSN: 2308-4944 (print) e-ISSN: 2409-0085 (online)

Year: $2019 \quad$ Issue: $05 \quad$ Volume: 73

Published: $30.05 .2019 \quad$ http://T-Science.org

SECTION 35. Immovable property. Land relations.

UDK 62-1
QR - Issue

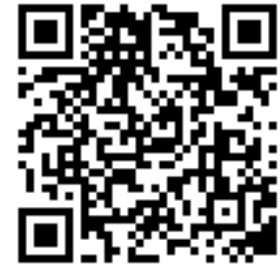

$$
\begin{aligned}
& \text { F.D. Nurmirzayev } \\
& \text { Master student, }
\end{aligned}
$$
Wuhan University of Technology, China

M.X. Abelqosimova teacher,

Namangan Engineering - Construction Institute

N.Sh. Mansurova teacher,

Namangan Engineering - Construction Institute

K.O. Sobirjonova teacher,

Namangan Engineering - Construction Institute

\title{
PRINCIPLES AND MEANS OF DEVELOPING HEATING AND VENTILATION SYSTEM OF MULTISTOREY RESIDENTIAL BUILDINGS
}

Abstract: In this article highlights of principles and means of developing heating and ventilation system of multistorey residential buildings and protecting and improving the environment as one of the problems of urban development.

Key words: ventilation, heating, multistorey, building, residential building.

Language: English

Citation: Nurmirzayev, F. D., Abelqosimova, M. X., Mansurova, N. S., \& Sobirjonova, K. O. (2019). Principles and means of developing heating and ventilation system of multistorey residential buildings. ISJ Theoretical \& Applied Science, 05 (73), 658-663.

Soi: http://s-o-i.org/1.1/TAS-05-73-104 Doi: crossef https://dx.doi.org/10.15863/TAS.2019.05.73.104

\section{Introduction}

Nowadays, environmental problems are growing economic and social importance. On the correct and timely solution to this problem depends on the health and well-being of not only living, but also future generations. Protecting and improving the environment as one of the problems of urban development - an integral part of design and planning work at all stages of design, starting with the general scheme of settling on a national scale, the region and ending with the project of detailed planning and techno work projects of individual elements of the city. At each level, the design has its own specifics in setting goals, objectives and selection of research methods and evaluation. At each stage of the design must take into account the complex factors influencing the biological and hygienic environment. The origin of these factors are divided into natural and anthropogenic. The natural concern climate, topography, soils, vegetation, surface water and groundwater. Among anthropogenic factors can be distinguished manufactured physical (noise, electromagnetic radiation, etc.), manufactured chemicals (air pollution, hydrosphere, soil) and mechanical manufactured (violation of topography and soil cover, deforestation, etc.). There are factors that activate each other fogs and release of toxic substances into the atmosphere, low temperatures and strong winds, solar radiation, and motor vehicle emissions and others. Some of them have the ability to potentiation in the environment, leading to a sharp increase in the integral index, which reflects the cumulative impact of all factors of the urban environment on human health. Among the climatic factors that have a significant influence on the external environment is wind and heat. Wind contributes to the 


\begin{tabular}{|c|c|c|c|c|c|c|}
\hline \multirow{4}{*}{ Impact Factor: } & ISRA (India) & $=3.117$ & SIS (USA) & $=0.912$ & ICV (Poland) & $=6.630$ \\
\hline & ISI (Dubai, UAI & $=0.829$ & РИНЦ (Russia & $=0.156$ & PIF (India) & $=1.940$ \\
\hline & GIF (Australia) & $=0.564$ & ESJI (KZ) & $=8.716$ & IBI (India) & $=4.260$ \\
\hline & JIF & $=1.500$ & SJIF (Morocco & $=5.667$ & OAJI (USA) & $=0.350$ \\
\hline
\end{tabular}

transfer of air masses with different physical properties (heat and cold, wet and dry), aligns the temperature differences between the individual parts of the city, and has a significant impact on the state of air pollution of the city. Analysis of urban planning practice in our country, along with examples of correct account of wind and thermal conditions in the construction of new and reconstruction of old cities (identified cases of insufficient use of wind capacity to regulate the thermal regime of architectural and planning tools, and here and there a discrepancy planning and development of climatic conditions exacerbate discomfort aeration mode area. This is partly explained by the fact that the currently valid regulations (QMQ 2.07.01-94) guidance on accounting for wind thermal regime relate only to cases of selecting the location of residential and industrial areas in the urban areas with respect to the prevailing winds (wind speed and repeatability to destinations in the cold and warm periods of the year). Special instructions related to registration and regulation of wind and thermal regime in the design of residential development in existing building codes are not available.

\section{Materials and Methods}

Specificity of climatic conditions and, in particular, wind and thermal regime so far taken into account only in the development of individual projects, mostly experimental. No differentiated approach to planning and building cities in different wind and thermal conditions, and urban areas in the same city. Currently, there is no benefit, which would have been scientifically proved methods of assessment and prediction of wind and thermal regime in the design of buildings. The need to fill this gap and identified the preparation of this work.

The purpose of this paper is to provide a thermal and thermal forming the foundations of the wind regime warm modern multi-storey residential buildings in hot dry climate. Wind (vector factors characterizing the speed and direction) is one of the leading climatic factors; He has the greatest influence on the formation of a microclimate of the environment (distribution of temperature and humidity, etc.), warm feeling of a person and the state of air pollution. The main objective of development is to provide designers rather simple methods of assessment and prediction of wind and thermal regime in order to optimize sanitation residential development. The accounting for wind and thermal regime should be addressed at all stages of urban planning, from the settlement system and ending with the detailed plan, with the evaluation methods and techniques of control of wind and thermal regime specific to each stage of urban planning. Accounting and control of wind and thermal regime should be implemented in conjunction with other environmental factors (radiation and thermal regime of air pollution and others.).
Assessment of the current state of wind and thermal conditions (aeration) of the construction site must be carried out prior to the development of design solutions development and serve as a basis for the adoption of certain planning decisions. Evaluation of the specificity of the local environmental conditions and developed based on an assessment of the existing state of wind and thermal conditions of aeration map area should serve as a basis for the location of cities with different national economic profile in the settlement system and the various functional areas in the city in order to prevent the demolition of contaminated air from the industrial cities and objects on other economic profile of the city and residential areas.

The criteria for assessing the comfort of wind and thermal regime are bio-hygienic standards and wind speed coefficients K (quantity that characterizes the ratio of wind speed in the construction area or in a particular reception building to the wind speed according to the meteorological station located near). The thermal background, humidity, thermal insulation properties of clothing, exercise, etc, determines changing the warm feeling of the person depending on the wind speed. During the summer breeze "removes" the feeling of heat, and in winter increases the feeling of cold: strong winds on $1-2 \mathrm{~m} / \mathrm{s}$ is equivalent to lowering the temperature by $2-3^{\circ} \mathrm{C}$. Effect of air mobility change by heat radiation and convection is reduced. When detecting the influence on the human body should take into account the wind speed of air temperature, since the cooling effect of the wind is temperature dependent motion of air (thermal equivalent air speed). At a wind speed of $1.5 \mathrm{~m} / \mathrm{s}$ equivalent to the heat normally clothed person will be: at a temperature of $21^{\circ} \mathrm{C}-5^{\circ} \mathrm{C}$, at a temperature of $32^{\circ} \mathrm{C}-2,5^{\circ} \mathrm{C}$, at a temperature of $43^{\circ} \mathrm{C}-1^{\circ} \mathrm{C}$ ( which is equivalent to reducing the temperature of the air respectively at 5,1 and $2 \cdot 5^{\circ} \mathrm{C}$ ). Central Asia, with temperatures above $40^{\circ} \mathrm{C}$ in the summer - the wind speed in the range of $1-4 \mathrm{~m} / \mathrm{s}$. Wind speed above 5 $\mathrm{m} / \mathrm{s}$ perceived by man unsatisfactory.

The basis for the rational distribution of functional areas can serve as compiled for a specific city map diagram zoning on temperature and wind regime (Ris4).Planning and construction of residential areas shall be based on landscape-climatic conditions, which determine in each case functional zoning territory, tracing and orientation of streets; methods of construction, landscaping and beautification; types of residential and public buildings and so on. At the same time in areas with effective wind, conditions should orient the street at an angle to the direction of the prevailing wind, and in areas with poor aeration regime - in the direction of the prevailing winds favorable points of the compass. When choosing a site for the functional areas of a residential area the main objective is to create a healthier environment for living and working conditions of the population with 


\begin{tabular}{|c|c|c|c|c|c|c|}
\hline \multirow{4}{*}{ Impact Factor: } & ISRA (India) & $=3.117$ & SIS (USA) & $=0.912$ & ICV (Poland) & $=6.630$ \\
\hline & ISI (Dubai, UAI & $=0.829$ & РИНЦ (Russia & $=0.156$ & PIF (India) & $=1.940$ \\
\hline & GIF (Australia) & $=0.564$ & ESJI (KZ) & $=8.716$ & IBI (India) & $=4.260$ \\
\hline & JIF & $=1.500$ & SJIF (Morocce & $=5.667$ & OAJI (USA) & $=0.350$ \\
\hline
\end{tabular}

the rational use of natural terrain features based on its evaluation of microclimate. For residential areas and neighborhoods should be given a territory that best meet sanitary requirements (dry, well-ventilated areas and protected against the ingress of cold strong winds, hot dry winds, dust storms, etc.), if possible close to the open water and green spaces. To improve the microclimate necessary to provide for measures aimed at creating optimal conditions for ventilation (maximum use of natural factor mobility and local convective air currents, protection against adverse winds) and radiation regime (optimal sun exposure, protection from excessive direct sunlight, reducing the intensity of the reflected exposure and the emission of solar radiation in the overheated environment). To create a comfortable microclimate conditions necessary differentiated approach to the development of entire districts of the city due to the terrain and the location of the site in the city with respect to the prevailing wind direction in order to ensure acceptable air velocity over most of the built-up area. Construction changes wind speed and direction, ruling on an open undeveloped territory and depending on the architectural composition creates a certain wind conditions.

The angle of the direction of the prevailing wind changed to $30-90^{\circ} \mathrm{C}$, and the ratio of wind speed ranges from 0.1 to 1.2 with respect to the ratio of wind speed according to the weather station is taken as 1 . Influence on the aerodynamics of its buildings have a position in the city and orientation of the building or planning techniques regarding the prevailing winds: the coefficient of wind speed in the areas of building, located on the windward edge of the city, $0.1-0.2$ higher than in similar methods of building, situated under the protection of the earlier building. Optimality criterion architectural composition development in conditions of high wind speeds is such a solution, in which almost the entire area of the territory is characterized by the development of wind speed ratio of $0.1-0.5$ times the initial wind speed $(\mathrm{K}=1)$; at low wind speeds optimality criterion is a planning solution, in which the ratio of wind speed is $0.5-1$ or more. To create such an environment the wind regime and should seek when choosing the composition of building to enhance the comfort of the human environment. The building, located perpendicular to the facade or at a slight angle $\left(30^{\circ} \mathrm{C}\right)$ to the prevailing wind is the best barrier on his way into the building. For building a zone of lower wind speeds, the depth of which is from 3 to $7 \mathrm{~N}$ windproof home. To calculate the area of "calm" area behind the building, you can use the formula (1) (for Serebrovsky F.L.):

$S_{\text {штт. }}=b \cdot \sin \gamma \cdot b(l-0,18 b)(1)$

Depending on the direction of the prevailing wind $\gamma, 1$ the length of the house and the depth of the wind shadow $b$.

To determine the size of the wind shadow behind the building $\mathrm{Nm}$, having a length less than $10 \mathrm{H}$, you can use the formula (for G.K.Goldstein):

$$
N_{m}=(10,84 H-W) K,(2)
$$

where W - width of the building shell, $\mathrm{m}$; K coefficient taking into account the length of the building, adopted according to the calculation according to NM Thomson; its value is given in Table. The value depends on the wind shadow of the geometric dimensions of the building. Its size increases with increasing height or length of the house and decrease its width. The distance between the facades of buildings should be taken with regard to their location relative to the direction of the prevailing favorable wind currents: parallel $-2 \mathrm{H}$; at an angle of $45^{\circ} \mathrm{C}-3 \mathrm{H}$; perpendicular - depending on the number of rows - from 3 to $5 \mathrm{H}$. Gaps between the ends of the buildings located facade to the direction of the prevailing winds should be taken: the purpose of less efficient ventilation building sites - up to $1 \mathrm{H}$, and for effective aeration territory - from 1 to $1,5 \mathrm{H}$ and more. When development of the territory should seek optimal architectural planning and design solutions development, that is, to this, which provides comfortable or conditions close to them at the lowest cost to the natural and artificial climate control for a long time: the horizontal building with gaps between buildings less $2,5 \mathrm{H}$ additional heat losses are at a level of $5 \%$ of the main; widening the gap to $3 \mathrm{H}$ leads to an increase in additional heat losses of up to $16-18 \%$ of the basic (in F.L.Serebrovsky). Orientation of buildings, taking into account the prevailing winter winds years reduces their additional heat loss by 10 $15 \%$, which is of great economic importance. 


\begin{tabular}{|c|c|c|c|c|c|c|}
\hline \multirow{4}{*}{ Impact Factor: } & ISRA (India) & $=3.117$ & SIS (USA) & $=0.912$ & ICV (Poland) & $=6.630$ \\
\hline & ISI (Dubai, UAE & $=0.829$ & РИНЦ (Russia) & $=0.156$ & PIF (India) & $=1.940$ \\
\hline & GIF (Australia) & $=0.564$ & ESJI (KZ) & $=8.716$ & IBI (India) & $=4.260$ \\
\hline & JIF & $=1.500$ & SJIF (Morocco & $=5.667$ & OAJI (USA) & $=0.350$ \\
\hline
\end{tabular}

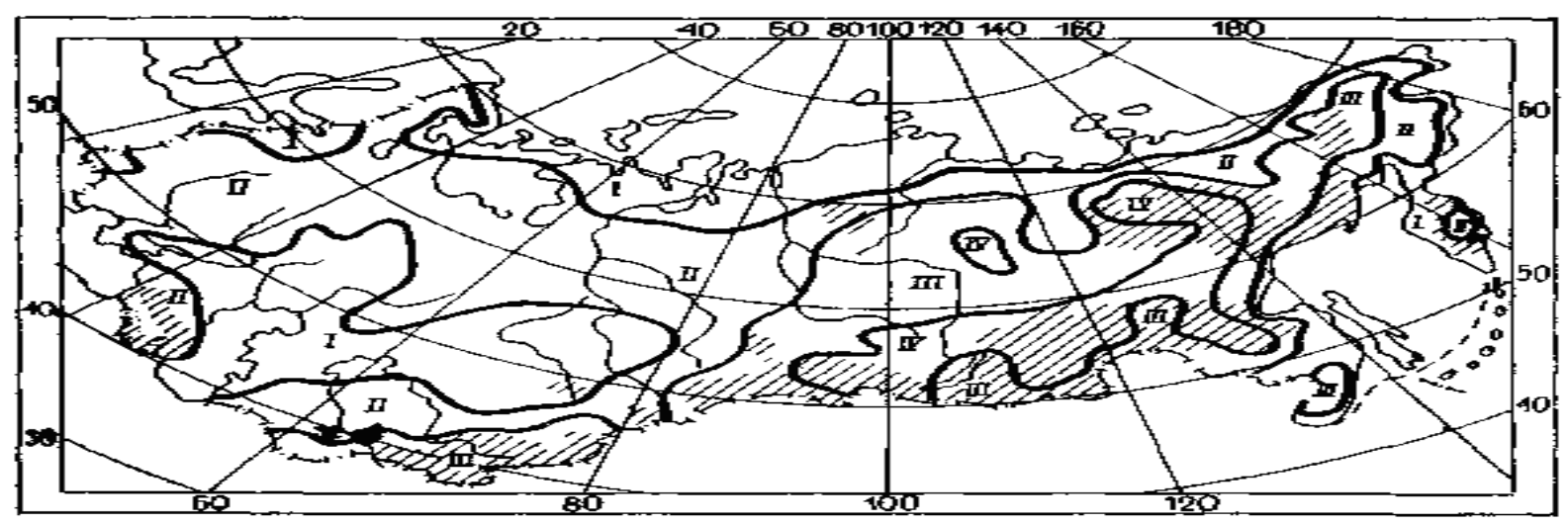

Figure 1. Schematic map of the area (I - IV) repeatability of wind speed $0-1 \mathrm{~m} / \mathrm{s}$.

\section{Conclusion}

The ability to predict wind conditions at the design stage by means of the proposed methods was hallmarked on the project of building area of Tashkent and other cities, as well as two versions of planning neighborhoods developed on the basis of the existing design solutions: the first option - in order to maximize the windshield area, the second in order to maximize ventilation area development. The results of evaluation of the wind regime of the project with the aim of solving neighborhood windshield area showed that in the comfort of wind conditions is $87.5 \%$ of the territory, free from development. Project residential district to enhance ventilation area showed that the territory of the building there is no wind conditions, which would be characterized by coefficients of wind speed less than 0.5 of its free-flow speed: the whole territory of the district effectively ventilated. Therefore, using the regularities found and applying the proposed technique can be at the stage of development of design decisions to lay the foundation of comfort wind regime territory of the future residential development.

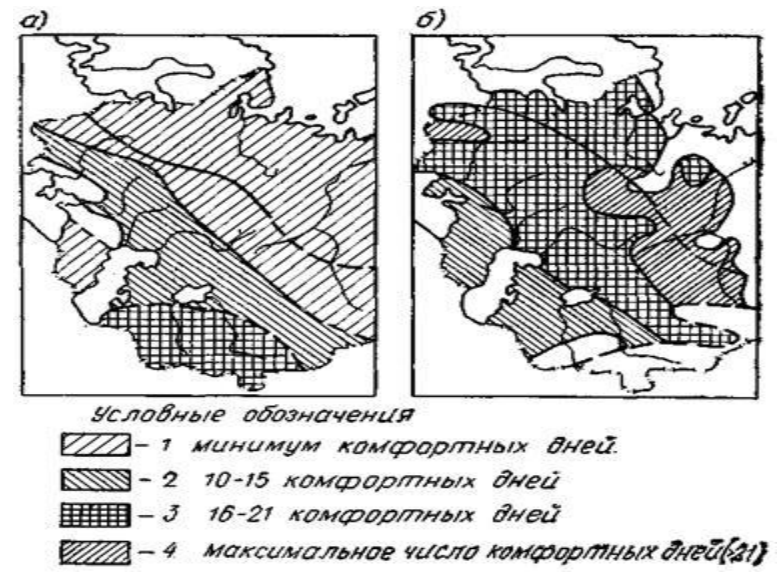

Figure 2. Maps of the distribution of the frequency of occurrence comfort warm feeling in plain areas of the Republic in June.

$a$ - in vivo; $b$ - for protection against wind. 


\begin{tabular}{|c|c|c|c|c|c|c|}
\hline \multirow{4}{*}{ Impact Factor: } & ISRA (India) & $=3.117$ & SIS (USA) & $=0.912$ & ICV (Poland) & $=6.630$ \\
\hline & ISI (Dubai, UAE & $=0.829$ & РИНЦ (Russia & $=0.156$ & PIF (India) & $=1.940$ \\
\hline & GIF (Australia) & $=0.564$ & ESJI (KZ) & $=8.716$ & IBI (India) & $=4.260$ \\
\hline & JIF & $=1.500$ & SJIF (Morocce & $=5.667$ & OAJI (USA) & $=0.350$ \\
\hline
\end{tabular}

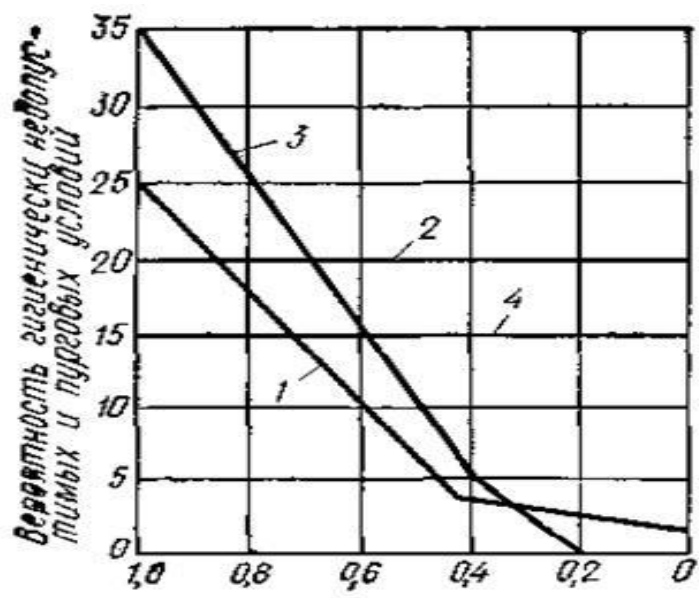

Figure 3. The effectiveness of windbreaks.

1-Severity of winter bio thermic conditions; 2-margin harsh winter conditions bio thermic; 3-blizzard conditions; 4-margin blizzard conditions.
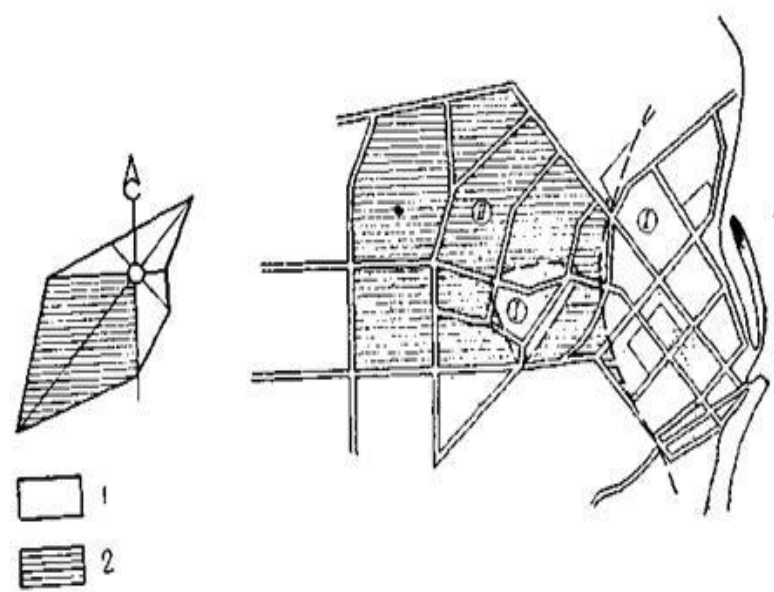

Figure 4. Schematic map of zoning on temperature and wind regime for urban development. 1 - a comfortable area of the city; 2 - an area that requires regulation wind conditions to achieve this goal were carried out comprehensive research questions and solved a number of scientific and practical problems which include; The regularities of formation of warm wind regime of modern multi-storey residential development set of criteria relations for integrated assessment of its effectiveness.

\section{References:}

1. Alekseev, Y. A. (2004). Aerodinamicheskie osobennosti pyatietazhnoy zastroyki Zhilishchnoe stroitel'stvo, M. № 6, pp. 5-6.

2. Ayzenshtat, B. A. (1985). O postuplenii potokov rasseyannoy radiatsii na vertikal'nye $i$ gorizontal'nye poverkhnosti $v$ usloviyakh gorodskoy zastroyki. Tr. SARNIGMI. T.. vyp 22/37 pp. $42-50$.
3. Ershov, A. V., Gol'dshteyn, G. K., Korbut, T. O. (1969). Rol' otrazhennoy radiatsii v usloviyakh zharkogo klimata. Stroitel'stvo i arkhitektura Sredney Azii, T. №4, pp. 43-44.

4. Gol'dshteyn, G. K. (1969). Mikroklimaticheskaya effektivnost' zastroyki razlichnoy etazhnosti v Sredney Azii Stroitel'stvo i arkhitektura Uzbekistana, T. №6, pp. 40-42. 


\begin{tabular}{|c|c|c|c|c|c|c|}
\hline \multirow{4}{*}{ Impact Factor: } & ISRA (India) & $=3.117$ & SIS (USA) & $=0.912$ & ICV (Poland) & $=6.630$ \\
\hline & ISI (Dubai, UAI & $=0.829$ & РИНЦ (Russia & $=0.156$ & PIF (India) & $=1.940$ \\
\hline & GIF (Australia) & $=0.564$ & ESJI (KZ) & $=8.716$ & IBI (India) & $=4.260$ \\
\hline & JIF & $=1.500$ & SJIF (Morocce & $=5.667$ & OAJI (USA) & $=0.350$ \\
\hline
\end{tabular}

5. Shukurov, I. S. (2005). Teplo vetrovoy rezhim zhiloy zastroyki v usloviyakh zharko shtilevogo i sukhogo klimata. Zhilishchnoe stroitel'stvo, №2, M. «Lad'ya», pp. 20-22c.

6. Alinazarov, A. K., \& Mukhiddinov, D. N. (1998). Gelioteplokhimtekhnologiya proizvodstva zolotsementnykh kompozitsionnykh materialov. (p.214). Namangan: Ibrat.

7. Nodirov, S. M., Alinazarov, A. K. (2001). The Effect of Calorific Power Control Accuracy on the Operation Modes of Solar Heat-generating Plants. Applied Solar Energy, Vol. 37, No. 3. Allerton Press, Ins. /New York, pp. 86-87.

8. Alinazarov, A. K. (2000). Effect of Solar Thermal Chemical Treatment on Deformable
Indices of Ash-Cement Compositions. Applied Solar Energy, Vol. 36, No. 3. Allerton Press, Ins. /New York, pp.70-73.

9. Alinazarov, A. K., Atamov, A. A., \& Mukhiddinov, D. N. (2001). Hydrophysical Properties of Ash-Cement Compositions and their Effect on Solar Thermical Chemical Treatment. Applied Solar Energy, Vol. 37, No. 1. Allerton Press, Ins. /New York, pp. 44-48.

10. Alinazarov, A. K., \& Mazhidov, N. N. (2001). Mathematical Modeling of Thermal Processes in the Helio-thermochemical Treatment of FineGrained Polirtructucal composite Products. Applied Solar Energy, Vol. 37, No. 2. Allerton Press, Ins. /New York, pp. 18-20. 
ISRA (India) $\quad \mathbf{=} \mathbf{3 . 1 1 7}$

Impact Factor: $\quad$ ISI (Dubai, UAE) $=\mathbf{0 . 8 2 9}$

GIF (Australia) $=\mathbf{0 . 5 6 4}$

JIF

$=1.500$
SIS (USA)

РИНЦ $($ Russia $)=0.156$

$\mathrm{ESJI}(\mathrm{KZ}) \quad=\mathbf{8 . 7 1 6}$

SJIF $($ Morocco $)=\mathbf{5 . 6 6 7}$
ICV (Poland)

PIF (India)

IBI (India)

$=6.630$ 